\title{
Characterization and evolution of the mitochondrial DNA control region in Ranidae and their phylogenetic relationship
}

\author{
Z.H. Huang ${ }^{1}$ and F.Y. Tu ${ }^{2}$ \\ ${ }^{1}$ Department of Life Sciences, School of Life Sciences, \\ Jinggangshan University, Ji'an, Jiangxi Province, China \\ ${ }^{2}$ Institute of Wildlife Protection, Jiangxi Academy of Forestry, \\ Nanchang, Jiangxi Province, China \\ Corresponding author: Z.H. Huang \\ E-mail: hzhow@163.com
}

Genet. Mol. Res. 15 (3): gmr.15038491

Received January 26, 2016

Accepted April 15, 2016

Published August 29, 2016

DOI http://dx.doi.org/10.4238/gmr.15038491

Copyright $(C 2016$ The Authors. This is an open-access article distributed under the terms of the Creative Commons Attribution ShareAlike (CC BY-SA) 4.0 License

\begin{abstract}
The control region is considered to be one of the most variable parts of animal mitochondrial DNA (mtDNA). We compared the mtDNA control region from 37 species representing 14 genera and 4 subfamilies of Ranidae, to analyze the evolution of the control region and to determine their phylogenetic relationship. All the Ranidae species had a single control region, except four species that had two repeat regions. The control region spanned the region between the $C y t b$ and $t R N A^{\text {leu }}$ genes in most of the Ranidae species. The length of the control region sequences ranged from 1186 bp (Limnonectes bannaensis) to $6746 \mathrm{bp}$ (Rana kunyuensis). The average genetic distances among the species varied from $1.94 \%$ (between $R$. chosenica and R. plancyi) to $113.25 \%$ (between Amolops ricketti and Euphlyctis
\end{abstract}


hexadactylus). The alignment of three conserved sequence blocks was identified. However, conserved sequence boxes F to A were not found in Ranidae. A maximum likelihood method was used to reconstruct the phylogenetic relationship based on a general time reversible + gamma distribution model. The amount of $\mathrm{A}+\mathrm{T}$ was higher than $\mathrm{G}+\mathrm{C}$ across the whole control region. The phylogenetic tree grouped members of the respective subfamilies into separate clades, with the exception of Raninae. Our analysis supported that some genera, including Rana and Amolops, may be polyphyletic. Control region sequence is an effective molecular mark for Ranidae phylogenetic inference.

Key words: Mitochondrial DNA; Control region; Ranidae; Phylogeny; Mitochondrial DNA structure

\section{INTRODUCTION}

Over the past few decades, frog species have been experiencing dramatic declines around the world. The amphibian decline crisis has prompted an extraordinary proliferation of research in various relevant areas (Navas et al., 2012). Mitochondrial DNA (mtDNA) has been widely used as a marker for evolutionary and conservation genetic studies, because of its compact size, nearly complete maternal inheritance, and fast evolutionary rate. The control region is the most polymorphic region of the animal mtDNA genome, presumably due to lack of coding constrains (Baker and Marshall, 1997). Thus, the control region sequence has become one of the most commonly used markers for the study of phylogenetic relationships and population genetics in animals (e.g., Li et al., 2012).

Numerous studies of the structure of mtDNA control region in fishes (e.g., Lee et al., 1995; Zhao et al., 2006), birds (e.g., Randi and Lucchini, 1998; Ruokonen and Kvist, 2002; Huang and Ke, 2016), and mammals (e.g., Fumagalli et al., 1996; Sbisà et al., 1997) have been conducted. However, the control region of frogs has only been studied in a limited number of species. Although large size variations in the frog mitochondrial genome are known, the extent to which this represents an expansion of the control region sequences is poorly understood. Recently, a large number of mitochondrial genomes have been reported, which has created a good opportunity for studies of control region structure and evolution of frogs.

In the present study, we examined the structure of the control region of Ranidae species, based on the complete mitochondrial genome collected from GenBank. The aims of this paper were: 1) to characterize the structural features and patterns of sequence evolution of the Ranidae mtDNA control region and 2) to infer the relationships of Ranidae using the mtDNA control region.

\section{MATERIAL AND METHODS}

All sequences were retrieved from GenBank (species and GenBank accession numbers are presented in Table 1). We only analyzed the control-region sequence from the whole mitochondrial genome, in order to ensure accuracy. A total of 37 species from 14 genera belonging to four subfamilies of Ranidae were analyzed (Table 1).

Genetics and Molecular Research 15 (3): gmr.15038491 
Sequences were aligned using the CLUSTAL X procedure (Thompson et al., 1997). DnaSP v. 5.0 (Librado and Rozas, 2009) was used to define the variable sites. The nucleotide composition was calculated using MEGA 6.0 (Tamura et al., 2013) and the genetic distance between species was calculated using the Tamura and Nei (1993) model (TN93) in MEGA 6.0 (Tamura et al., 2013). The conserved sequence boxes found were compared with previously published sequences (e.g., Sano et al., 2005).

MODELTEST 3.0 (Posada and Crandall, 1998) and the Akaike information criterion (AIC, Posada and Buckley, 2004) were used to identify the appropriate nucleotide substitution models. A maximum likelihood (ML) tree (Strimmer and Haeseler, 1996) was obtained using heuristic searches, based on the substitution model proposed by MODELTEST 3.0 (Posada and Crandall, 1998). The ML tree was constructed using PAUP 4.0 (Swofford, 2002). Leiopelma archeyi and L. hochstetteri were used as outgroup. Statistical support for the internodes in the phylogenetic tree was tested by bootstrap percentages (BP) based on 1000 replicates (Felsenstein, 1985). Some species had more than one control region sequence, in which case we only used one homologous sequence to construct the phylogenetic tree.

\section{RESULTS AND DISCUSSION}

\section{Alignments}

The alignment of the Ranidae control region was straightforward. Most of the Ranidae species had only a single control region, with the exception of four species (Euphlyctis hexadactylus, Hoplobatrachus tigerinus, Hyperolius marmoratus, and Rana kunyuensis), which had two repeat regions. The control region spans the region between the Cyt $b$ and $t R N A^{\text {leu }}$ genes in most Ranidae species (Table 1). This is different from most of the avian species wherein the control region spans between $t R N A^{G l u}$ and $t R N A^{\text {Phe }}$ (e.g., Huang and Ke, 2016).

The length of the control region sequences were highly variable, ranging from $1186 \mathrm{bp}$ (Limnonectes bannaensis) to $6746 \mathrm{bp}$ (R. kunyuensis), with an average size of $2717 \mathrm{bp}$ (Table 1). The size and variation of the Ranidae control region was larger than that observed in the avian family Phasianidae (ranging from 1144 to 1555 bp, Huang and Ke, 2016). The control region is usually considered to be the most variable part of the mtDNA (Randi and Lucchini, 1998). Extensive size variation of the mtDNA control region, attributable to variation in the number of tandem repeats, has been reported in many animals (e.g., Boyce et al., 1989; Rand and Harrison, 1989).

\section{Base composition and genetic distance}

The average nucleotide composition of the Ranidae control region sequences was as follows: $31.34 \% \mathrm{~A}, 33.37 \% \mathrm{~T}, 12.89 \% \mathrm{G}$, and $22.41 \% \mathrm{C}$, with a bias against $\mathrm{G}$. The amount of $\mathrm{A}+\mathrm{T}$ was more than that of $\mathrm{G}+\mathrm{C}$ across the whole control region, which was also found in the avian control region (e.g., Baker and Marshall, 1997; Ruokonen and Kvist, 2002; Huang and Ke, 2016).

The nucleotide frequencies were not significantly different among species, and thus the TN93 model is an appropriate estimator of genetic distance (Randi and Lucchini, 1998). We were able to align the Ranidae control region sequences with high certainty within each genus. Genetic distances between species ranged from $1.94 \%$ (between $R$. chosenica and $R$. plancyi) to $113.25 \%$ (between Amolops ricketti and E. hexadactylus), showing a wide range of divergences.

Genetics and Molecular Research 15 (3): gmr.15038491 
Table 1. Size and location of the mitochondrial DNA control region in Ranidae.

\begin{tabular}{|c|c|c|c|c|c|c|}
\hline Subfamily & Genus & Species & Code & Size (bp) & Location & GenBank accession No. \\
\hline \multirow{4}{*}{ Amolopinae } & \multirow[t]{4}{*}{ Amolops } & Mantzorum & Ama & 2211 & $\mathrm{a}$ & $\mathrm{NC} 024180$ \\
\hline & & Ricketti & Ari & 2404 & $\mathrm{a}$ & NC023949 \\
\hline & & Tormotus & Ato & 2583 & $\mathrm{~b}$ & NC009423 \\
\hline & & Wuyiensis & Awu & 2435 & $\mathrm{a}$ & NC025591 \\
\hline \multirow[t]{18}{*}{ Raninae } & Babina & Adenopleura & $\mathrm{Bad}$ & 3159 & $\mathrm{a}$ & NC018771 \\
\hline & Glandirana & Tientaiensis & Gti & 2336 & $\mathrm{a}$ & NC025226 \\
\hline & Hylarana & Guentheri & Hgu & 3128 & $\mathrm{a}$ & NC024748 \\
\hline & \multirow[t]{2}{*}{ Odorrana } & Margaretae & Oma & 2501 & $\mathrm{~b}$ & NC024603 \\
\hline & & Ishikawae & Ois & 4913 & $\mathrm{~b}$ & NC015305 \\
\hline & \multirow[t]{5}{*}{ Pelophylax } & Cretensis & Pcr & 2453 & $\mathrm{a}$ & NC025575 \\
\hline & & Cypriensis & Pcy & 2648 & $\mathrm{a}$ & NC026893 \\
\hline & & Epeiroticus & Pep & 2654 & $\mathrm{a}$ & NC026894 \\
\hline & & Kurtmuelleri & Pku & 2643 & $\mathrm{a}$ & NC026895 \\
\hline & & Shqipericus & Psh & 1986 & $\mathrm{a}$ & NC026896 \\
\hline & \multirow[t]{8}{*}{ Rana } & Catesbeiana & Rca & 2783 & $\mathrm{a}$ & NC022696 \\
\hline & & Chensinensis & Rch & 3222 & $\mathrm{a}$ & NC023529 \\
\hline & & Chosenica & Rco & 2977 & $\mathrm{a}$ & NC016059 \\
\hline & & Dybowskii & Rdy & 3412 & $\mathrm{a}$ & NC023528 \\
\hline & & Kunyuensis & Rku & 6746 & $\mathrm{a}$ & NC024548 \\
\hline & & Nigromaculata & Rni & 2425 & $\mathrm{a}$ & NC002805 \\
\hline & & Plancyi & Rpl & 2437 & $\mathrm{a}$ & NC009264 \\
\hline & & Sylvatica & Rsy & 1713 & $\mathrm{a}$ & KP222281 \\
\hline \multirow[t]{14}{*}{ Dicroglossinae } & Euphlyctis & Hexadactylus & Ehe & 4783 & c & NC014584 \\
\hline & \multirow[t]{2}{*}{ Fejervarya } & Cancrivora & Fca & 2441 & $\mathrm{~d}$ & NC012647 \\
\hline & & Limnocharis & Fli & 2180 & $\mathrm{~d}$ & NC005055 \\
\hline & Hoplobatrachus & Rugulosus & Hru & 2990 & $\mathrm{~d}$ & NC019615 \\
\hline & & Tigerinus & $\mathrm{Hti}$ & 5001 & $\mathrm{a}$ & NC014581 \\
\hline & \multirow[t]{3}{*}{ Limnonectes } & Bannaensis & Lba & 1186 & $\mathrm{a}$ & NC012837 \\
\hline & & Fragilis & Lfr & 1322 & $\mathrm{a}$ & AY899241 \\
\hline & & Fujianensis & Lfu & 1577 & $\mathrm{e}$ & NC007440 \\
\hline & \multirow[t]{3}{*}{ Nanorana } & Parkeri & Npa & 2259 & $\mathrm{a}$ & NC026789 \\
\hline & & Pleskei & $\mathrm{Npl}$ & 2143 & $\mathrm{a}$ & NC016119 \\
\hline & & Taihangnica & Nta & 1972 & $\mathrm{a}$ & NC024272 \\
\hline & \multirow[t]{3}{*}{ Quasipaa. } & Boulengeri & Pbo & 2047 & $\mathrm{a}$ & NC021937 \\
\hline & & Spinosa & Psp & 2524 & $\mathrm{a}$ & NC013270 \\
\hline & & $Y e i$ & Pye & 1580 & $\mathrm{a}$ & NC024843 \\
\hline Occidozyginae & Occidozyga & Martensii & Oma & 2766 & d & NC014685 \\
\hline \multirow[t]{2}{*}{ Outgroup } & Leiopelma & Archeyi & & 851 & & NC014691 \\
\hline & & Hochstetteri & & 944 & & $\mathrm{NC} 027072$ \\
\hline
\end{tabular}

a: Cyt b-Leu, b: Cyt b-His, c: Cyt b-Pro, d: Cyt b-ND5, e: Glu-Leu.

\section{Conserved sequences}

Previous comparisons of control region sequences have identified conserved sequence elements based on greater similarity of the sequence elements compared to that of the flanking areas (e.g., Ruokonen and Kvist, 2002; Huang and Ke, 2016). We aligned the sequences of all species and identified three conserved sequence blocks (CSB-1, -2, and -3) located in the Ranidae (Table 2). CSB-1, -2 and -3 were also detected in fish (e.g., Zhang et al., 2011), bird (e.g., Baker and Marshall, 1997; Yang et al., 2015), and mammalian species (e.g., Walberg and Clayton, 1981). We did not find the CBS-1 in Nanorana pleskei; the CSB-2 was not found in $N$. pleskei, Quasipaa yei, or Fejervarya limnocharis; and the CSB-3 was not observed in N. pleskei, Quasipaa yei, or Occidozyga martensii. Conserved sequence boxes (F to A) are often found in fishes (e.g., Zhang et al., 2011), birds (e.g., Randi and Lucchini, 1998; Huang and Ke, 2016), and mammals (e.g., Walberg and Clayton, 1981). However, these were not found in Ranidae. 
Table 2. Sequences for the conserved sequence blocks (CSB-1, -2, and -3) of the Ranidae species.

\begin{tabular}{|c|c|}
\hline Species code* & CSB-1 \\
\hline Ois & TAAATGAATGCTCGAATGACATA \\
\hline Ato & TTAATGAATGCTCGAATGACATA \\
\hline Oma & TAAATGAATACTAGATGGACATA \\
\hline Ama & TTAATTAATGCTTAAATGACATA \\
\hline $\mathrm{Bad}$ & TTAATGAATGCTCAATGGACACA \\
\hline Hgu & $\begin{array}{l}\text { TTAATGAATGCTCAATGGACATA } \\
\end{array}$ \\
\hline Gti & AAAATGAATGCTAGATTGACATA \\
\hline Pcy, Pku & TTAGTGAATGCTAGAATGACATA \\
\hline Pcr & TTAGTGAATGCTATAATGACATA \\
\hline Psh & TTAATGAATGCTAGAATGACATA \\
\hline Rco, Rpl, Rni & \begin{tabular}{|l} 
TTAATGAATGCTATAATGACATA \\
\end{tabular} \\
\hline Pep & TTACTGAATGCTAGAATGACATA \\
\hline Rca & TTAATTAATGTTAGATTGACATA \\
\hline Rsy & \begin{tabular}{|l|} 
TTAAATAATGCTAGATTGACATA \\
\end{tabular} \\
\hline Rku & TCAATGAATGCTCGAATGACATC \\
\hline Rch & \begin{tabular}{|l} 
TTAATTAATGCTCAAATGACATA \\
\end{tabular} \\
\hline Rdy & TTAATTAATGCTAAAATGACATA \\
\hline Ari & TCAATTAATGCTAAAACGACATA \\
\hline Awu & \begin{tabular}{|l|} 
TCAATTAATGCTAGAAGGACATA \\
\end{tabular} \\
\hline Omr & CCACTCCATGTAGTACCACTATA \\
\hline $\mathrm{Npa}$ & TAAATGAATGCTAGATGGACATA \\
\hline $\mathrm{Nta}$ & TAGATGAATGCTAGACGGACATA \\
\hline Pbo & TAAATGAATGCTTGACGGACATA \\
\hline Psp & TTAGTGAATGCTTGACGGACATA \\
\hline Pye & TAAATGAATGCTTGATGGACATA \\
\hline Fca & TTAATTAATGCTAGAATGACATA \\
\hline Fli & TTAATTAATGTTAAATTGACATA \\
\hline Hru, Hti & CCTATTAATGCTTGATGGACATA \\
\hline Ehe & CTTATGCATGCTAGTCGGACATA \\
\hline \multirow[t]{2}{*}{ Lba, Lfu } & TCTAATGAATGCTCGACGGACATA \\
\hline & CSB-2 \\
\hline Ato & TTТАССССССССТА-СССССССС \\
\hline Ois & CTТАССССССССТТТСССССССС \\
\hline Oma & СТТАССССССССТА-СССССССС \\
\hline Ama & GGTACСССССССТTTCССССССC \\
\hline Bad, Hgu, Npa, Psp, Lba & ССТАССССССССТТАСССССССС \\
\hline Gti, Rca, Rsy & GTTACСССССССТАTTCСССССC \\
\hline Pcy, Pku & ACAАССССССССТТТСССССССС \\
\hline Pcr & ATAАССССССССТT-СССССССС \\
\hline Psh & ATAACСССССССТTТСССССССC \\
\hline Rco, Rpl, Rni & AGAACСССССССТTTСССССССС \\
\hline Pep & GCAАССССССССТTTСССССССС \\
\hline Rku, Rch & TATACСССССССТTТСССССССС \\
\hline Rdy & AATACСССССССТTTCССССССC \\
\hline Omr, Nta, Pbo, Fca, Lfr & GCTACСССССССТTACССССССC \\
\hline Ari, Awu & GCTACСССССССТTTCCСССССC \\
\hline Lfu & СCТАСССССССССТTСССССССС \\
\hline Ehe & ACТАСССССССССТАСССССССС \\
\hline \multirow[t]{2}{*}{ Hru, Hti } & $\begin{array}{l}\text { GCAACСССССССТTACССССССС } \\
\end{array}$ \\
\hline & CSB-3 \\
\hline Ois & CCTTAAAACCCCCCCCCGA \\
\hline Ato, Oma & CCTTAAAACCCCCCCC-GA \\
\hline Ama & CCATAAAAACCCCCCCCGA \\
\hline $\mathrm{Bad}$ & CCTCAA--CCCCCCCCCGA \\
\hline Hgu, Psh, Rco, Rpl, Rni, Rca, Rsy, Rku, Rch & CCTTAAT-CCCCCCCCCGA \\
\hline Gti, Awu & CCTTAAAA-CCCCCCCCGA \\
\hline Pcy, Pku, Pcr, Pep & CCTTGAAA-CCCCCCCCGA \\
\hline Rdy & CCTTAAT-СССССССССАA \\
\hline Ari & CCTTAAA-CCCCCCCCCGA \\
\hline $\mathrm{Npa}$ & TCCTAATACCCCCCCCCGG \\
\hline $\mathrm{Nta}$ & \begin{tabular}{|l|} 
CCCTAATT--CCCCCCCAG \\
\end{tabular} \\
\hline Pbo & \begin{tabular}{|l} 
TCCTAACA-CCCCCCCCAG \\
\end{tabular} \\
\hline Psp & TCCTAATACCСССССCCAG \\
\hline Fca & TCCTCCTACCCCCCCCCGA \\
\hline Fli & TGCTGCTACCCCCCCCCGA \\
\hline Hru & AACCCCAG--CCCCCCCGA \\
\hline Hti, Ehe & \begin{tabular}{|l} 
TATTCTAGCCCCCCCCCGA \\
\end{tabular} \\
\hline Lba & CTCCTAAT--CCCCСCCAG \\
\hline Lfu & CCCCTAAT--CCCCCCCGA \\
\hline Lfr & TTCCTAAT-CCCCCCCCAG \\
\hline
\end{tabular}

Genetics and Molecular Research 15 (3): gmr.15038491 


\section{Phylogenetic relationships}

On the basis of hierarchical likelihood-ratio tests as implemented in MODELTEST 3.0, the general time reversible (GTR) model + gamma (G) distribution was used (GTR + $\mathrm{G} ;-\operatorname{lnL}=14653.47, \mathrm{P}<0.001, \mathrm{AIC}=29475.58, \mathrm{BIC}=30149.04)$. We set the shape of the gamma distribution to 2.08 (as estimated by MODELTEST). An ML method was used to reconstruct the phylogenetic tree based on the GTR + G model. Many clades were supported by bootstrap values of more than $80 \%$. With the exception of Raninae, the phylogenetic tree grouped members of the same subfamily into the same clade (Figure 1).

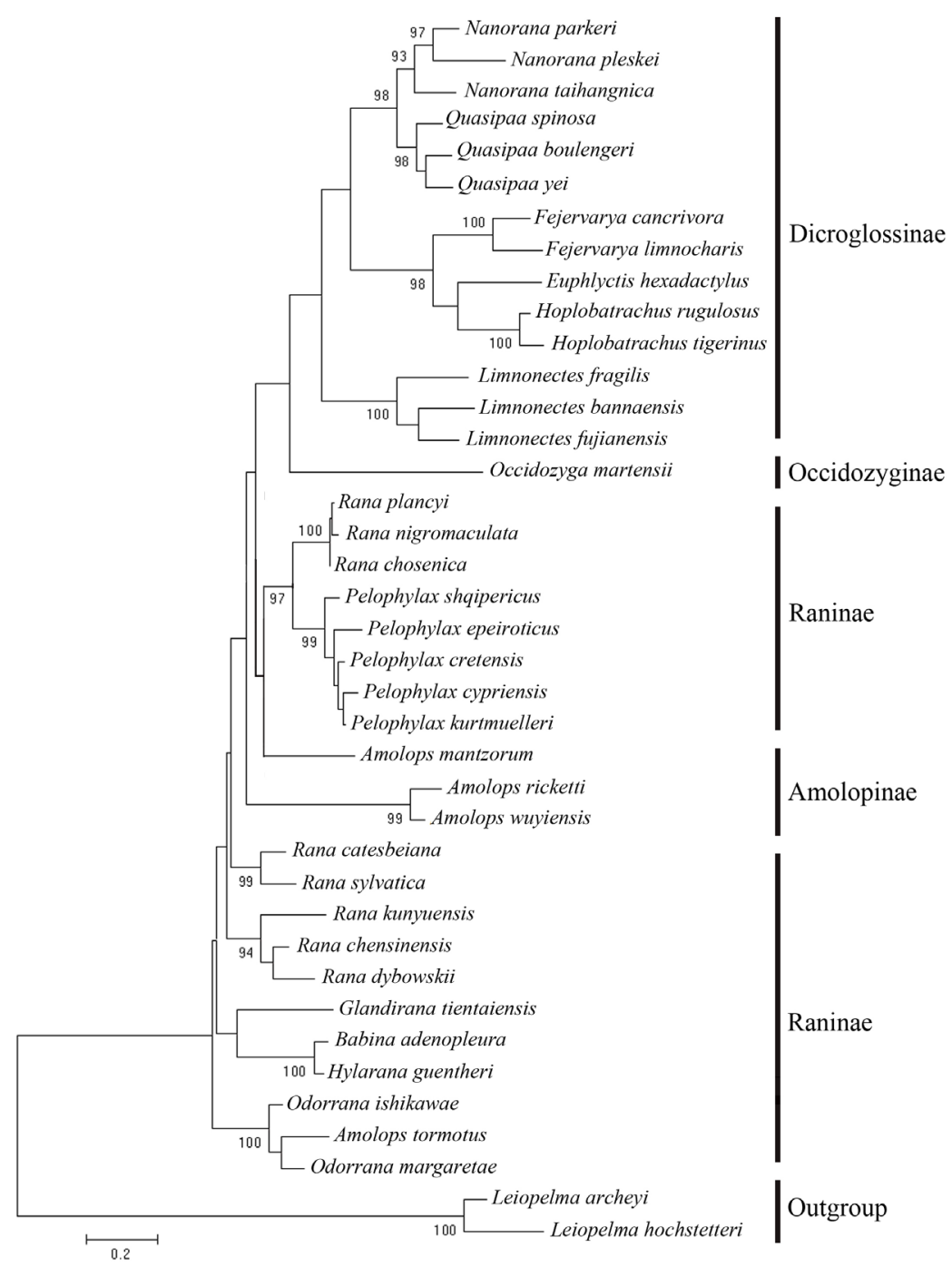

Figure 1. Phylogenetic tree of Ranidae constructed from control region sequences. Numbers (at internodes) represent bootstrap values $(>90 \%)$ based on 1000 replications. The species codes are as shown in Table 1 .

Genetics and Molecular Research 15 (3): gmr.15038491 
The phylogenetic tree grouped all the species of Dicroglossinae into one clade (Figure 1). Control region gene analysis strongly supported that the genera Nanorana and Quasipaa formed a single clade $(\mathrm{BP}=98 \%)$. Euphlyctis was the sister genus of Hoplobatrachus that together formed a sister group of the genus Fejervarya $(\mathrm{BP}=98 \%)$. Limnonectes formed a separate clade $(\mathrm{BP}=100 \%)$.

Members of Occidozyginae also formed a single sister clade to the Dicroglossinae (Figure 1). The taxonomic position of Occidozyga has previously been debated. Dubois (1992) suggested that Occidozyga shared several important unique characters with the genus Euphlyctis, and proposed to place the genera Euphlyctis, Occidozyga, and Phrynoglossus as a Dicroglossini tribe within the subfamily Dicroglossinae. However, Emerson and Berrigan (1993) suggested Occidozyga as a subgenus of Rana. Che et al. (2007) proposed that Occidozyga was the sister taxon of Micrixalus using 12S and 16S rRNA. Marmayou et al. (2000) found that the genera Occidozyga and Phrynoglossus formed a basal clade. In our study, the control region sequences supported that Occidozyga (belonging to Occidozyginae) formed a sister group of the Dicroglossinae (Figure 1). To better resolve the taxonomic status of Occidozyga, more taxon sampling, as well as multiple nuclear markers are needed in future studies.

The species of Raninae were divided into two different clades. The species within a genus grouped together in each clade, except for the genera Rana and Amolops (Figure 1). Rana is the most diverse genus within the Raninae. Many phylogenetic studies have suggested that Rana might not be monophyletic based on molecular data (e.g., Hillis and Wilcox, 2005; Jiang and Zhou, 2005; Che et al., 2007; Huang et al., 2014). Control region data supported the hypothesis of polyphyly for Rana. Likewise, the systematics of Amolops species has long been contended, especially A. tormotus (e.g., Fei, 1999; Li et al., 2006; Cai et al., 2007; Su et al., 2007). A. tormotus was originally named Rana tormotus by Wu (1977). Fei et al. (1991) instead suggested that tormotus should be transferred to the genus Amolops, based on morphological characters. Cai et al. (2007) suggested the transfer of A. tormotus into the genus Odorrana based on $12 \mathrm{~S}$ and 16S rRNA. Huang et al. (2014) also considered that $A$. tormotus should be transferred to the genus Odorrana as $O$. tormota based on COI gene analysis. Our control region data also showed that $A$. tormotus was the sister species to $O$. margaretae (Figure 1). Thus, our results support that A. tormotus should be placed in the genus Odorrana as O. tormota.

In this study, the characteristics in the pattern of variability in the Ranidae mitochondrial control region were analyzed. The size of the Ranidae control region is highly variable. We examined the existence of the previously described conserved sequence blocks of the control region by using wide variety of species, both fishes, avian and mammalian. Only CSB-1, -2, -3 were observed. However, conserved sequence boxes (F to A) are not detected in Ranidae. We also inferred the phylogenetic relationships of Ranidae using control region. With the exception of Raninae, the phylogenetic tree grouped members of the same subfamily into the one clade. Control region sequence is an effective molecular tool for phylogenetic inference of Ranidae.

\section{Conflicts of interest}

The authors declare no conflict of interest.

\section{ACKNOWLEDGMENTS}

Research supported by the National Natural Science Foundation of China (\#31260088,

Genetics and Molecular Research 15 (3): gmr.15038491 
\#31560590), the Jiangxi Province Talent Project 555, the Jiangxi Province Major Disciplines Academic Leaders (\#20133BCB22010), the Natural Science Foundation of Jiangxi Province (\#20132BAB204022, \#20152ACB21006), and the Science and Technology Foundation of Jiangxi Provincial Department of Education (\#GJJ150768).

\section{REFERENCES}

Baker AJ and Marshall HD (1997). Mitochondrial control region sequences as tools for understanding evolution. In: Avian molecular evolution and systematics (Mindell DP, ed.). Academic Press, San Diego, 51-82.

Boyce TM, Zwick ME and Aquadro CE (1989). Mitochondrial DNA in the bark weevils: size, structure and heteroplasmy. Genetics 123: 825-836.

Cai HX, Che J, Pang JF, Zhao EM, et al. (2007). Paraphyly of Chinese Amolops (Anura, Ranidae) and phylogenetic position of the rare Chinese frog, Amolops tormotus. Zootaxa 1531: 49-55.

Che J, Pang J, Zhao H, Wu GF, et al. (2007). Molecular phylogeny of the Chinese ranids inferred from nuclear and mitochondrial DNA sequences. Biochem. Syst. Ecol. 35: 29-39. http://dx.doi.org/10.1016/j.bse.2006.09.003

Dubois A (1992). Notes sur la classification des Ranidae (Amphibiens, Anoures). Bull. Mens. Soc. Linn. Lyon 61: 305-352.

Emerson SB and Berrigan D (1993). Systematics of southeast Asian ranids: multiple origins of voicelessness in the subgenus Limnonectes (Fitzinger). Herpetologica 49: 22-31.

Fei L (1999). Atlas of amphibians of China. Henan Science and Technology Press, Zhengzhou, China, 376-378.

Fei L, Ye CY and Huang YZ (1991). Key to Chinese Amphibia. Chongqing Branch, Publishing House of Science and Technology Materials, Chongqing, China, 164-168.

Felsenstein J (1985). Confidence limits on phylogenies: an approach using the bootstrap. Evolution 39: 783-791. http:// dx.doi.org/10.2307/2408678

Fumagalli L, Taberlet P, Favre L and Hauser J (1996). Origin and evolution of homologous repeated sequences in the mitochondrial DNA control region of shrews. Mol. Biol. Evol. 13: 31-46. http://dx.doi.org/10.1093/oxfordjournals. molbev.a025568

Hillis DM and Wilcox TP (2005). Phylogeny of the New World true frogs (Rana). Mol. Phylogenet. Evol. 34: 299-314. http://dx.doi.org/10.1016/j.ympev.2004.10.007

Huang ZH and Ke DH (2016). Structure and evolution of the Phasianidae mitochondrial DNA control region. Mitochondrial DNA 27: 350-354. http://dx.doi.org/10.3109/19401736.2014.895987

Huang ZH, Yang CZ and Ke DH (2014). DNA barcoding and molecular phylogeny in Ranidae. Mitochondrial DNA 29: $1-5$.

Jiang J and Zhou K (2005). Phylogenetic relationships among Chinese ranids inferred from sequence data set of $12 \mathrm{~S}$ and 16S rDNA. Herpetol. J. 15: 1-8.

Lee W J, Conroy J, Howell WH and Kocher TD (1995). Structure and evolution of teleost mitochondrial control regions. J. Mol. Evol. 41:54-66. http://dx.doi.org/10.1007/BF00174041

Li HY, Xu TJ, Cheng YZ, Sun DQ, et al. (2012). Genetic diversity of Setipinna taty (Engraulidae) populations from the China Sea based on mitochondrial DNA control region sequences. Genet. Mol. Res. 11: 1230-1237. http://dx.doi. org/10.4238/2012.May.9.1

Li PP, Lu YY and Lü SQ (2006). Taxonomic status of Rana tormotus Wu, 1977 with description of a new genus of subfamily Raninae. Sichuan J. Zool. 25: 206-209.

Librado P and Rozas J (2009). DnaSP v5: A software for comprehensive analysis of DNA polymorphism data. Bioinformatics 25: 1451-1452. http://dx.doi.org/10.1093/bioinformatics/btp187

Marmayou J, Dubois A, Ohler A, (2000). Phylogenetic relationships in the Ranidae (Amphibia, Anura): independent origin of direct development in the genera Philautus and Taylorana. Comptes Rendus de l Académie des Sciences Series III - Sciences de la Vie 323: 287-297. http://dx.doi.org/10.1016/S0764-4469(00)00133-5

Navas CA, Bevier CR and Carnaval AC (2012). Integrative and objective science is the best link between amphibian decline research and conservation on the ground. Alytes 29: 119-132.

Posada D and Crandall KA (1998). MODELTEST: testing the model of DNA substitution. Bioinformatics 14: 817-818. http://dx.doi.org/10.1093/bioinformatics/14.9.817

Posada D and Buckley TR (2004). Model selection and model averaging in phylogenetics: Advantages of Akaike information criterion and Bayesian approaches over likelihood ratio tests. Syst. Biol. 53: 793-808. http://dx.doi. org $/ 10.1080 / 10635150490522304$

Rand DM and Harrison RG (1989). Molecular population genetics of mtDNA size variation in crickets. Genetics 121:

Genetics and Molecular Research 15 (3): gmr.15038491 
551-569.

Randi E and Lucchini V (1998). Organization and evolution of the mitochondrial DNA control region in the avian genus Alectoris. J. Mol. Evol. 47: 449-62. http://dx.doi.org/10.1007/PL00006402

Ruokonen M and Kvist L (2002). Structure and evolution of the avian mitochondrial control region. Mol. Phylogenet. Evol. 23: 422-432. http://dx.doi.org/10.1016/S1055-7903(02)00021-0

Sano N, Kurabayashi A, Fujii T, Yonekawa H, et al. (2005). Complete nucleotide sequence of the mitochondrial genome of Schlegel's tree frog Rhacophorus schlegelii (family Rhacophoridae): duplicated control regions and gene rearrangements. Genes Genet. Syst. 80: 213-224. http://dx.doi.org/10.1266/ggs.80.213

Sbisà E, Tanzariello F, Reyes A, Pesole G, et al. (1997). Mammalian mitochondrial D-loop region structural analysis: identification of new conserved sequences and their functional and evolutionary implications. Gene 205: 125-140. http://dx.doi.org/10.1016/S0378-1119(97)00404-6

Strimmer K and Haeseler AV (1996). Quartet puzzling: a quartet maximum likelihood method for reconstructing tree topologies. Mol. Biol. Evol. 13: 964-969. http://dx.doi.org/10.1093/oxfordjournals.molbev.a025664

$\mathrm{Su} \mathrm{X}, \mathrm{Wu} \mathrm{XB}$, Yan P, Cao SY, et al. (2007). Rearrangement of a mitochondrial tRNA gene of the concave-eared torrent frog, Amolops tormotus. Gene 394: 25-34. http://dx.doi.org/10.1016/j.gene.2007.01.022

Swofford D (2002). PAUP*: Phylogenetic analysis using parsimony and other methods. Sinauer Associates, Sunderland.

Tamura K and Nei M (1993). Estimation of the number of nucleotide substitutions in the control region of mitochondrial DNA in humans and chimpanzees. Mol. Biol. Evol. 10: 512-526.

Tamura K, Stecher G, Peterson D, Filipski A, et al. (2013). MEGA6: Molecular evolutionary genetics analysis version 6.0. Mol. Biol. Evol. 30: 2725-2729. http://dx.doi.org/10.1093/molbev/mst197

Thompson JD, Gibson TJ, Plewniak F, Jeanmougin F, et al. (1997). The CLUSTAL_X windows interface: flexible strategies for multiple sequence alignment aided by quality analysis tool. Nucleic Acids Res. 24: 4876-4882. http:// dx.doi.org/10.1093/nar/25.24.4876

Walberg MW and Clayton DA (1981). Sequence and properties of the human KB cell and mouse L cell D-loop regions of mitochondrial DNA. Nucleic Acids Res. 9: 5411-5421. http://dx.doi.org/10.1093/nar/9.20.5411

Wu GF (1977). A new species of frogs from Huangshan, Anhui-Rana tormotus Wu. Acta Zool. Sin. 23: 113-115.

Yang C, Lian T, Wang QX, Huang Y, et al. (2015). Structural characteristics of the Relict Gull (Larus relictus) mitochondrial DNA control region and its comparison to other Laridae. Mitochondrial DNA DOI:10.3109/194017 36.2015.1033711.

Zhang Y, Zhang H, Gao TX and Miao ZQ (2011). Structure of mitochondrial DNA control region and molcular phylogenetic relationship among three flounders of genus Pleuronectes. Biochem. Syst. Ecol. 39: 627-634. http:// dx.doi.org/10.1016/j.bse.2011.05.008

Zhao JL, Wang WW, Li SF and Cai WQ (2006). Structure of the mitochondrial DNA control region of the sinipercine fishes and their phylogenetic relationship. Acta Genet. Sin. 33: 793-799. http://dx.doi.org/10.1016/S0379-4172(06)60112-1

Genetics and Molecular Research 15 (3): gmr.15038491 